\title{
Analisis Pengaruh Kebijakan Hutang dan Ukuran Perusahaan terhadap Nilai Perusahaan dengan Agency Cost sebagai Variabel Intervening

\author{
(Studi pada Perusahaan Manufaktur yang Terdaftar di Bursa Efek
} Indonesia (BEI) Periode 2014-2017)
}

\author{
Santry Afriani Dewi ${ }^{1}$, Firman Surya ${ }^{2}$ dan Zahara ${ }^{3}$ \\ ${ }^{1}$ Jurusan Akuntansi, Politeknik Negeri Padang \\ Email:santryafrianidewi0@gmail.com \\ 2 Jurusan Akuntansi, Politeknik Negeri Padang \\ Email:firm4n2003@gmail.com \\ 3 Jurusan Akuntansi, Politeknik Negeri Padang \\ Email:zahara.ak@gmail.com
}

\begin{abstract}
ABSTRAK
Penelitian ini bertujuan untuk menguji pengaruh kebijakan hutang dan ukuran perusahaan terhadap nilai perusahaan melalui agency cost sebagai variabel intervening. Sampel penelitian ini adalah perusahaan manufaktur yang terdaftar di Bursa Efek Indonesia (BEI) periode 2014-2017. Data dikumpulkan dengan metode purposive sampling dengan jumlah 106 perusahaan. Metode analisis yang digunakan adalah analisis jalur dan pengolahan data dengan menggunakan SPSS versi 20. Berdasarkan hasil pengujian disimpulkan bahwa secara parsial kebijakan hutang tidak berpengaruh negatif terhadap agency cost, ukuran perusahaan tidak berpengaruh positif terhadap agency cost, kebijakan hutang tidak berpengaruh positif terhadap nilai perusahaan, ukuran perusahaan berpengaruh positif terhadap nilai perusahaan, agency cost tidak berpengaruh negatif terhadap nilai perusahaan, serta kebijakan hutang tidak berpengaruh positif terhadap nilai perusahaan melalui agency cost sebagai variabel intervening, dan ukuran perusahaan tidak berpengaruh negatif terhadap nilai perusahaan melalui agency cost sebagai variabel intervening.
\end{abstract}

Kata Kunci: Kebijakan hutang, ukuran perusahaan, agency cost, nilai perusahaan, analisis jalur

\begin{abstract}
The purpose of this research is to examine the effect of debt policy and firm size on firm value by agency cost as intervening variable. The sample of this research is manufacturing company listed on the Indonesia Stock Exchange in the period of 2014-2017. Data was collected using purposive sampling method with total of 106 companies. The analytical method used is path analysis and data processing using SPSS version 20. Based on the test results concluded that partially debt policy does not negatively affect on agency cost, firm size does not have a positive effect on agency cost, debt policy does not have a positive effect on firm value, firm size has a positive effect on firm value, agency cost has no negative effect on firm value, and debt policy does not have a positive effect on firm value by agency cost as intervening variable, and firm size does not negatively affect firm value through agency cost as intervening variable.
\end{abstract}




\section{PENDAHULUAN}

Indonesia merupakan salah satu negara yang memiliki pertumbuhan industri manufaktur yang cukup tinggi. Saat ini kenaikan pangsa pasar industri manufaktur nasional berdampak pada peringkat daya saing industri, yang meningkat ke posisi sembilan sepanjang tahun 2015-2017, dari sebelumnya di posisi 12 pada tahun 2014. Direktur Jenderal Industri Logam Mesin Alat Transportasi dan Elektronika (ILMATE), I Gusti Putu Suryawirawan mengatakan, pertumbuhan sektor manufaktur mengalami peningkatan yang signifikan dari tumbuhnya permintaan baik dari lokal dan global. Kondisi inflasi saat ini mendorong industri lokal mengurangi kuota impor bahan industri dan memanfaatkannya dari produsen lokal (Kumparan.com).

Dengan meningkatnya daya saing industri di Indonesia khususnya pada industri manufaktur, membuat perusahaan-perusahaan tersebut berlomba-lomba untuk meningkatkan nilai perusahaannya. Nilai perusahaan yang telah go public tercerminkan dari harga saham yang diperjualbelikan di pasar modal atau yang biasa dikenal dengan Bursa Efek Indonesia (Suharli, 2006). Setiap perusahaan akan selalu menunjukkan kepada calon investor bahwa perusahaan mereka tepat dan layak sebagai alternatif untuk berinvestasi. Maka perusahaan tersebut harus mampu menampilkan sinyal yang baik tentang nilai perusahaannya.

Di Indonesia telah banyak peneliti yang melakukan penelitian tentang faktorfaktor yang berpengaruh terhadap nilai perusahaan. Namun masih banyak menunjukkan perbedaan hasil. Beberapa faktor diantaranya adalah kebijakan hutang, ukuran perusahaan dan agency cost.

Kebijakan hutang dapat dihubungkan dengan nilai perusahaan, karena selain bagi investor, pandangan tentang nilai perusahaan juga penting bagi pihak kreditur. Bagi pihak kreditur nilai perusahaan berkaitan dengan likuiditas perusahaan, yaitu perusahaan dinilai mampu atau tidaknya mengembalikan pinjaman yang diberikan (Analisa, 2011). Apabila nilai perusahaan dipandang tidak baik maka investor juga akan menilai perusahaan dengan rendah. Jika perusahaan dinilai rendah oleh investor, maka investor tidak akan tertarik untuk berinvestasi atau membeli saham di perusahaan tersebut, sehingga rendahnya permintaan beli atas saham menyebabkan turunnya harga saham dan nilai perusahaan akan menurun. Jadi, adanya kebijakan pendanaan perusahaan yang berasal dari pinjaman kepada kreditur atau yang disebut dengan kebijakan hutang merupakan salah satu faktor yang menentukan pandangan investor mengenai nilai perusahaan.

Ukuran perusahaan dapat didefinisikan sebagai penilaian seberapa besar atau kecil perusahaan yang diwakili oleh aset, jumlah penjualan, rata-rata total penjualan dan total aset rata-rata. Dengan demikian, ukuran perusahaan adalah ukuran atau jumlah aset yang dimiliki oleh perusahaan. Jika perusahaan dengan total aset besar menunjukkan bahwa perusahaan memiliki arus kas yang baik atau positif, sehingga dianggap memiliki prospek yang baik dalam jangka panjang. Hal ini juga 
mencerminkan bahwa perusahaan relatif lebih stabil dan lebih mampu menghasilkan keuntungan dari perusahaan dengan total aset kecil (Putu et al). Selain itu, perusahaan-perusahaan besar dianggap memiliki kontrol yang lebih baik (greater control) terhadap kondisi pasar, sehingga mereka mampu menghadapi persaingan ekonomi, yang membuat mereka menjadi kurang rentan terhadap fluktuasi ekonomi. Perusahaan-perusahaan besar juga mempunyai lebih banyak sumber daya untuk meningkatkan nilai perusahaan karena memiliki akses yang lebih baik terhadap sumber-sumber informasi eksternal dibandingkan dengan perusahaan kecil. Ukuran perusahaan yang besar menunjukkan perusahaan mengalami perkembangan sehingga investor akan merespon positif dan nilai perusahaan akan meningkat (Ernawati dan Widyawati, 2015). Semakin besar perusahaan atau skala perusahaan maka akan semakin mudah pula perusahaan memperoleh sumber pendanaan baik bersifat internal maupun eksternal, sehingga juga dapat meningkatkan nilai perusahaan (Dewi dan Wirajaya, 2013). Berdasarkan anggapan ini, maka ukuran perusahaan juga menjadi salah satu faktor yang menentukan nilai perusahaan.

Namun adakalanya perusahaan tidak berhasil dalam meningkatkan nilai perusahaannya. Hal tersebut dapat disebabkan karena pihak manajemen bukanlah pemegang saham (Ernawati dan Widyawati, 2015). Perusahaan memerlukan manajer sebagai agen yang menjalankan kegiatan perusahaan karena pemegang saham khususnya pemegang saham yang baru tidak memiliki pengetahuan yang mendalam terhadap perusahaan dimana mereka menginvestasikan uangnya. Sehingga para pemegang saham (pemilik) membayar jasa profesional pihak manajemen dan harus mengeluarkan biaya untuk meyakinkan agar manajer bekerja sungguh-sungguh untuk kepentingan pemegang saham yang disebut dengan biaya keagenan (agency cost).

Penggunaan hutang dalam struktur modal dapat mencegah pengeluaran perusahaan yang tidak penting dan memberi dorongan pada manajer untuk mengoperasikan perusahaan dengan lebih efisien (Jansen dan Mecling, 1976). Hal tersebut menyebabkan agency cost berkurang dan selanjutnya kinerja perusahaan diharapkan akan meningkat yang akan berdampak pada meningkatnya nilai perusahaan. Dalam kaitannya dengan ukuran perusahaan, menurut Kaen dan Baumann (2003) semakin besar ukuran perusahaan maka semakin kompleks masalah agensi yang dihadapi. Hal ini karena perusahaan dengan ukuran besar sulit memonitoring, sehingga menyebabkan agency cost yang semakin meningkat. Perusahaan dengan agency cost yang tinggi akan menurunkan laba perusahaan. Perusahaan dengan laba yang rendah membuat investor tidak tertarik untuk berinvestasi di perusahaan tersebut sehingga rendahnya permintaan beli atas saham yang menyebabkan harga saham terus menurun dan nilai perusahaan juga ikut menurun.

Jadi faktor-faktor seperti kebijakan hutang, ukuran perusahaan, dan agency cost dianggap mampu mempengaruhi nilai perusahaan. Seperti penelitian dilakukan oleh Pracihara (2016) yang menemukan hasil bahwa kebijakan hutang mempunyai 
pengaruh negatif terhadap nilai perusahaan. Namun berbeda dengan hasil penelitian yang dilakukan Immanuela (2014) yang menemukan hasil bahwa kebijakan hutang tidak berpengaruh terhadap nilai perusahaan. Beberapa peneliti lain menemukan hasil bahwa ukuran perusahaan berpengaruh positif terhadap nilai perusahaan seperti penelitian yang dilakukan oleh Sofyaningsih dan Hardiningsih (2011). Tetapi berbeda dengan penelitian yang dilakukan oleh Dewi dan Wirajaya (2013), dan Immanuela (2014) yang menemukan hasil bahwa ukuran perusahaan tidak berpengaruh terhadap nilai perusahaan. Sementara itu Pratiwi, Tandika dan Nurdin (2017) menemukan hasil bahwa struktur modal yang diukur dengan DER berpengaruh negatif terhadap agency cost, sedangkan ukuran perusahaan tidak berpengaruh terhadap agency cost. Di sisi lain, Fachrudin (2011) menemukan hasil penelitian bahwa struktur modal yang diproksikan dengan DER berpengaruh positif terhadap agency cost, ukuran perusahaan berpengaruh negatif terhadap agency cost, sementara struktur modal, ukuran perusahaan dan agency cost tidak mempunyai pengaruh terhadap kinerja perusahaan, serta tidak terdapat pengaruh tidak langsung struktur modal dan ukuran perusahaan terhadap kinerja perusahaan melalui agency cost sebagai intervening variable.

Keberagaman dari beberapa hasil penelitian di atas juga memberikan motivasi kepada saya untuk meneliti bagaimana pengaruh kebijakan hutang dan ukuran perusahaan terhadap nilai perusahaan melalui agency cost sebagai variabel intervening pada perusahaan manufaktur yang terdaftar di Bursa Efek Indonesia (BEI) pada tahun 2014 sampai 2017, yaitu ditahun mulai meningkatnya peringkat daya saing industri manufaktur di Indonesia sehingga membuat setiap perusahaan manufaktur semakin ingin meningkatkan nilai perusahaannya. Seperti yang dijelaskan di atas, bahwa nilai perusahaan yang go public tercermin dari harga sahamnya. Namun rata-rata harga saham perusahaan manufaktur pada empat tahun tersebut mengalami penurunan yang dapat dilihat dari grafik di bawah ini:

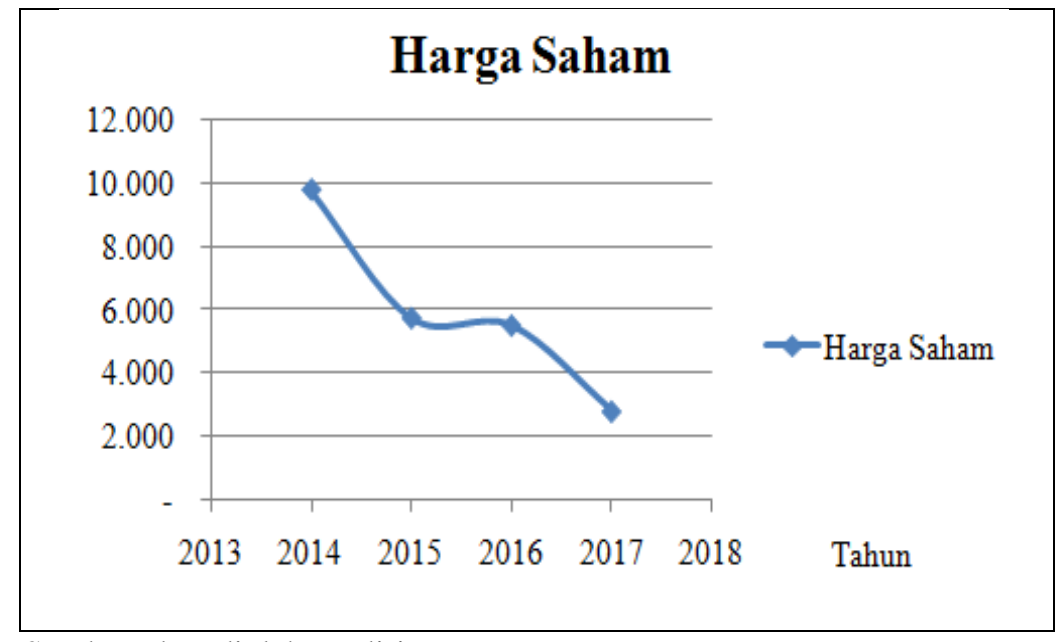

Sumber: data diolah sendiri

Gambar 1: Rata-rata Harga Saham Perusahaan Manufaktur tahun 2014-2017 
Dengan adanya peningkatan peringkat daya saing industri manufaktur, perusahaan tersebut berlomba-lomba untuk meningkatkan nilai perusahaan yang tercermin dari peningkatan harga saham. Namun dari grafik di atas dapat dilihat bahwa rata-rata harga saham perusahaan manufaktur mengalami penurunan sejak terjadinya peningkatan peringkat daya saing industri tersebut. Jadi, peneliti ingin meneliti bagaimana faktor-faktor internal seperti kebijakan hutang, ukuran perusahaan, dan agency cost mempengaruhi nilai perusahaan atau apakah kebijakan hutang dan ukuran perusahaan berpengaruh terhadap nilai perusahaan melalui agency cost.

\section{TINJAUAN PUSTAKA}

\section{Nilai Perusahaan}

Dalam mengambil keputusan keuangan, manajer keuangan perlu menentukan tujuan yang harus dicapai. Keputusan keuangan yang tepat dapat memaksimumkan nilai perusahaan sehingga mampu meningkatkan kemakmuran pemilik perusahaan. Nilai perusahaan sendiri merupakan harga yang bersedia dibayar oleh calon pembeli apabila perusahaan tersebut dijual (Dewi dan Wirajaya, 2013).

Menurut Harmono (2011:50), nilai perusahaan dapat diukur melalui nilai harga saham di pasar modal, yang merupakan refleksi penilaian oleh publik terhadap kinerja perusahaan secara riil. Dikatakan secara riil karena terbentuknya harga di pasar merupakan titik-titik kestabilan kekuatan permintaan dan titik-titik kestabilan kekuatan penawaran harga yang secara riil terjadi transaksi jual beli surat berharga di pasar modal antara para penjual (emiten) dan para investor.

Pendapat tersebut hampir sama dengan pendapat Silveira dan Barros (2007), yang mendefinisikan nilai perusahaan sebagai apresiasi/penghargaan investor terhadap sebuah perusahaan. Nilai tersebut tercermin pada harga saham perusahaan. Investor yang menilai perusahaan memiliki prospek yang baik di masa depan akan cenderung membeli saham perusahaan tersebut. Akibatnya permintaan saham yang tinggi menyebabkan harga saham meningkat. Sehingga dapat disimpulkan bahwa harga saham yang meningkat menunjukan bahwa investor memberikan nilai yang tinggi terhadap perusahaan. Dengan meningkatnya harga saham pemegang saham akan mendapatkan keuntungaan melalui capital gains.

\section{Kebijakan Hutang}

Kebijakan hutang merupakan salah satu alternatif pendanaan perusahaan selain menjual saham di pasar modal. Hutang adalah instrumen yang sangat sensitif terhadap perubahan nilai perusahaan. Semakin tinggi proporsi hutang, maka semakin tinggi harga saham, namun pada titik tertentu peningkatan hutang akan menurunkan nilai perusahaan karena manfaat yang diperoleh dari penggunaan hutang lebih kecil 
dari pada biaya yang ditimbulkannya. Para pemilik perusahaan lebih suka jika perusahaan menciptakan hutang pada tingkat tertentu untuk menaikkan nilai perusahaan (Nuraina, 2012).

Menurut Brigham dan Houston (2006:40), penggunaan hutang merupakan alternatif lain dalam mengubah struktur modal dengan harapan adanya persyaratan penutupan hutang yang lebih tinggi akan memaksa manajer untuk lebih disiplin. Jika hutang tidak ditutupi seperti yang diharuskan, perusahaan akan terpaksa dinyatakan bangkrut, di mana dalam kasus seperti ini manajer-manajernya akan kehilangan pekerjaan mereka. Karena itu, seorang manajer akan memiliki kemungkinan kecil menggunakan arus kas bebas perusahaan jika perusahaan memiliki persyaratan penutupan hutang yang besar yang dapat menyebabkan manajer tersebut kehilangan pekerjaannya.

\section{Ukuran Perusahaan}

Ukuran perusahaan dapat didefinisikan sebagai penilaian seberapa besar atau kecil perusahaan yang diwakili oleh aset, jumlah penjualan, rata-rata total penjualan dan total aset rata-rata (Putu et al). Ukuran perusahaan merupakan salah satu faktor yang dianggap mampu mempengaruhi nilai perusahaan. Perusahaan besar memiliki kontrol yang lebih baik (greater control) terhadap kondisi pasar, sehingga mereka mampu menghadapi persaingan ekonomi, yang membuat mereka menjadi kurang rentan terhadap fluktuasi ekonomi. Selain itu, perusahaan-perusahaan besar mempunyai lebih banyak sumber daya untuk meningkatkan nilai perusahaan karena memiliki akses yang lebih baik terhadap sumber-sumber informasi eksternal dibandingkan dengan perusahaan kecil (Ernawati, 2015).

\section{Agency Cost}

Pada situasi tertentu, tujuan manajemen kemungkinan berbeda dengan tujuan para pemegang saham (pemilik). Dalam perusahaan besar, para pemegang saham terbagi secara menyebar luas. Pada kondisi yang demikian, para pemegang saham hanya memiliki daya kendali yang terbatas terhadap jalannya operasi perusahaan. Ketika pengendalian perusahaan terpisah dari para pemilik, manajemen memiliki kecenderungan tidak selalu mewakili kepentingan pemilik, melainkan akan bertindak sebagai pemuas melalui pemaksimalan profit yang bersifat jangka pendek dibanding ke arah maksimalisasi kekayaan para pemegang saham atau nilai perusahaan yang mengarah pada kelangsungan hidup perusahaan. Manajemen akan bertindak lebih pada keamanan dirinya pada tingkat pertumbuhan perusahaan dalam toleransi yang bisa diterima. Dengan kata lain, manajemen akan lebih mengutamakan eksistensinya dibanding pemaksimalan kekayaan pemilik (Harmono, 2011:2). 
Setiap kemungkinan tindakan yang dilakukan oleh menajemen, tidak selalu menunjukkan bahwa pihak manajemen akan selalu berupaya untuk menguntungkan kepentingan mereka dengan merugikan pihak pemegang saham, tetapi hanya untuk menunjukkan kemungkinan hal-hal tersebut terjadi. Karena itulah diperlukan berbagai cara untuk memonitor (yang menimbulkan berbagai biaya) keputusankeputusan yang diambil oleh manajemen (Husnan dan Pudjiastuti, 1998). Biaya-biaya tersebut disebut dengan agency cost (Biaya keagenan).

Menurut Atmaja (1999:13), biaya keagenan (agency cost) adalah biaya yang dikeluarkan pemegang saham (pemilik) untuk meyakinkan agar manajer bekerja sungguh-sungguh untuk kepentingan pemegang saham. Biaya agensi dikeluarkan agar pihak yang diberi wewenang dapat bertindak sesuai keinginan pemilik, biayabiaya agensi tersebut yaitu : Pengeluaran untuk melakukan pengawasan (monitoring cost), biaya yang dikeluarkan pemilik untuk mencegah agar tindakan manajer tetap sesuai dengan kepentingannya. Biaya yang dikeluarkan untuk menjamin agar manajer tidak mengambil keuntungan dan fasilitas yang diberikan (bonding cost). Biaya yang dikeluarkan pemilik untuk mengembalikan citra perusahaan dan kesan yang buruk karena adanya perbedaan keputusan antara prinsipal dan agen (residual loss). Pengawasan secara total terhadap kegiatan para manajer akan memecahkan masalah keagenan, tetapi dibutuhkan biaya yang mahal.

\section{Hipotesis Penelitian}

Berdasarkan tinjauan pustaka yang telah dikemukakan di atas, maka hipotesis penelitian ini adalah sebagai berikut:

\section{Pengaruh kebijakan hutang terhadap agency cost}

Penggunaan hutang dalam struktur modal dapat mencegah pengeluaran perusahaan yang tidak penting dan memberi dorongan pada manajer untuk mengoperasikan perusahaan dengan lebih efisien. Hal tersebut menyebabkan agency cost berkurang. (Jensen dan Meckling, 1976). Jadi, semakin besar jumlah hutang menyebabkan semakin kecilnya jumlah agency cost. Menurut Pratiwi, Tandika dan Nurdin (2017), dengan penggunaan hutang yang tinggi, maka manajer akan mengurangi pengeluaran yang tidak penting supaya perusahaan tetap dapat membayar bunga maupun hutang pokok.

Berdasarkan hal tersebut, maka hipotesis pertama yang dapat diajukan adalah sebagai berikut:

$\mathrm{H}_{1}$ : Kebijakan hutang berpengaruh negatif terhadap agency cost.

\section{Pengaruh ukuran perusahaan terhadap agency cost}


Selain pengaruh kebijakan hutang terhadap agency cost, ukuran perusahaan dapat berpengaruh terhadap agency cost, .mengindikasikan bahwa perusahaan besar mengeluarkan lebih banyak beban-beban discretionary. Menurut Kaen dan Baumann (2003) semakin besar ukuran perusahaan maka semakin kompleks masalah agensi yang dihadapi. Hal ini karena perusahaan dengan ukuran besar sulit memonitoring, sehingga menyebabkan agency cost yang semakin meningkat.

Berdasarkan hal tersebut, maka hipotesis kedua yang dapat diajukan adalah sebagai berikut:

$\mathrm{H}_{2}$ : Ukuran perusahaan berpengaruh positif terhadap agency cost.

\section{Pengaruh kebijakan hutang terhadap nilai perusahaan}

Bagi perusahaan yang menerbitkan saham di pasar modal, harga saham yang diperjualbelikan di bursa merupakan indikator nilai perusahaan. Semakin tinggi harga saham semakin tinggi pula nilai perusahaan (Ernawati, 2015). Kebijakan mengenai struktur modal melibatkan trade off antara risiko dan tingkat pengembalian. Penambahan utang pada titik tertentu akan meningkatkan tingkat pengembalian yang diharapkan yang akan menaikkan harga saham tersebut (Sofyaningsih dan Hardiningsih, 2014). Modigliani dan Miller (1963) dalam Budiati (2013) berpendapat bahwa semakin tinggi proporsi hutang pada suatu perusahaan maka nilai perusahaan akan semakin meningkat. Hal ini disebabkan karena adanya keuntungan dari pengurangan pajak karena adanya pembayaran bunga yang dibayarkan oleh perusahaan sebagai akibat dari penggunaan hutang.

Berdasarkan hal tersebut, maka hipotesis ketiga yang dapat diajukan adalah sebagai berikut:

$\mathrm{H}_{3}$ : Kebijakan hutang berpengaruh positif terhadap nilai perusahaan.

\section{Pengaruh ukuran perusahaan terhadap nilai perusahaan}

Ukuran perusahaan dalam penelitian ini merupakan cerminan besar kecilnya perusahaan. Dalam hal ukuran perusahaan dilihat dari total assets yang dimiliki oleh perusahaan, yang dapat dipergunakan untuk kegiatan operasi perusahaan. Jika perusahaan memiliki total assets yang besar, pihak manajemen memiliki kemudahan dalam mengendalikan perusahaan yang akan meningkatkan nilai perusahaan (Analisa, 2011). Ukuran perusahaan yang besar dapat mencerminkan jika perusahaan mempunyai komitmen yang tinggi untuk terus memperbaiki kinerjanya, sehingga pasar akan membayar lebih mahal untuk mendapatkan sahamnya karena percaya akan mendapatkan pengembalian yang menguntungkan dari perusahaan tersebut (Dewi dan Wirajaya, 2013). Ukuran perusahaan yang besar cenderung memiliki kondisi yang lebih stabil. Kondisi tersebut menjadi penyebab atas naiknya harga saham perusahaan di 
pasar modal (Ernawati dan Widyawati, 2015).

Berdasarkan hal tersebut, maka hipotesis keempat yang dapat diajukan adalah sebagai berikut:

$\mathrm{H}_{4}$ : Ukuran perusahaan berpengaruh positif terhadap nilai perusahaan.

\section{Pengaruh agency cost terhadap nilai perusahaan}

Biaya keagenan (agency cost) adalah biaya yang dikeluarkan pemegang saham (pemilik) untuk meyakinkan agar manajer bekerja sungguh-sungguh untuk kepentingan pemegang saham (Atmaja, 1999). Jadi, jika biaya keagenan semakin rendah maka akan meningkatkan laba perusahaan. Laba perusahaan yang tinggi dipandang sebagai hal yang positif bagi investor untuk berinvestasi sehingga tingginya permintaan beli atas saham perusahaan tersebut yang mengakibatkan harga saham naik dan nilai perusahaan menjadi meningkat. Begitu pula sebaliknya, jika biaya keagenan semakin tinggi maka akan menurunkan laba perusahaan yang mengakibatkan investor tidak tertarik untuk berinvestasi di perusahaan tersebut. Dengan sedikitnya permintaan beli atas saham perusahaan tersebut membuat harga saham terus menurun dan nilai perusahaan juga ikut menurun.

Berdasarkan hal tersebut, maka hipotesis ketiga yang dapat diajukan adalah sebagai berikut:

$\mathrm{H}_{3}$ : Agency cost berpengaruh negatif terhadap nilai perusahaan.

\section{Pengaruh kebijakan hutang terhadap nilai perusahaan melalui agency cost sebagai variabel intervening}

Penggunaan hutang dalam struktur modal dapat mencegah pengeluaran perusahaan yang tidak penting dan memberi dorongan pada manajer untuk mengoperasikan perusahaan dengan lebih efisien (Jensen dan Meckling, 1976). Hal tersebut menyebabkan agency cost berkurang dan laba perusahaan akan meningkat. Dengan meningkatnya laba perusahaan maka akan dipandang positif oleh investor sehingga banyak investor akan tertarik untuk berinvestasi diperusahaan tersebut yang menyebabkan tingginya permintaan atas saham. Tingginya permintaan atas saham membuat harga saham terus meningkat yang mencerminkan nilai perusahaan juga meningkat.

Berdasarkan hal tersebut, maka hipotesis ketiga yang dapat diajukan adalah sebagai berikut:

$\mathrm{H}_{3}$ : Kebijakan hutang berpengaruh positif terhadap nilai perusahaan dengan agency cost sebagai variabel intervening 


\section{Pengaruh ukuran perusahaan terhadap nilai perusahaan melalui agency cost sebagai variabel intervening}

Dalam kaitannya dengan ukuran perusahaan, semakin besar ukuran perusahaan maka semakin kompleks masalah agensi yang dihadapi. Hal ini karena perusahaan dengan ukuran besar sulit memonitoring, sehingga menyebabkan agency cost yang semakin meningkat. Meningkatnya agency cost akan menurunkan laba perusahaan. Laba perusahaan yang rendah membuat investor tidak tertarik untuk berinvestasi di perusahaan tersebut sehingga rendahnya permintaan beli atas saham yang menyebakan terus menurunnya harga saham dan nilai perusahaan juga menurun.

Berdasarkan hal tersebut, maka hipotesis ketiga yang dapat diajukan adalah sebagai berikut:

$\mathrm{H}_{3}$ :Ukuran perusahaan berpengaruh negatif terhadap nilai perusahaan melalui agency cost sebagai variabel intervening

Keterkaitan kebijakan hutang, ukuran perusahaan, agency cost, dan nilai perusahaan dapat dilihat dalam rancangan model penelitian di bawah ini:

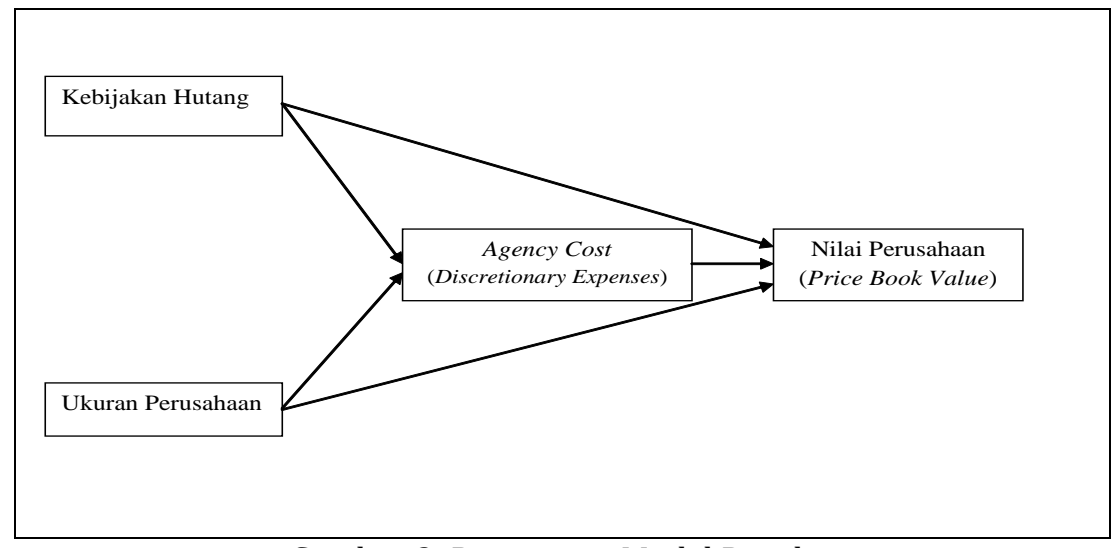

Gambar 2: Rancangan Model Penelitian

\section{METODE PENELITIAN}

Jenis penelitian ini adalah penelitian kuantitatif. Populasi penelitian ini adalah seluruh perusahaan manufaktur yang terdaftar di Bursa Efek Indonesia (BEI) periode penelitian 2014 sampai 2017 yang berjumlah 152 perusahaan. Data yang digunakan adalah data sekunder yang bersumber dari dokumentasi perusahaan. Sumber data yang digunakan adalah pada laporan tahunan yang telah diaudit pada perusahaan manufaktur yang terdaftar di Bursa Efek Indonesia selama periode 2014 sampai 
2017 yang didownload di website Bursa Efek Indonesia (www.idx.co.id). Sampel dipilih dengan metode purposive sampling yaitu pengambilan sampel dengan kriteria atau pertimbangan yang ditetapkan dengan harapan peneliti mendapatkan sampel yang representatif. Adapun kriteria-kriteria yang digunakan dalam pemilihan sampel adalah: 1) Perusahaan yang merupakan kelompok industri manufaktur di BEI selama periode penelitian yaitu tahun 2014-2017, 2) Perusahaan yang mempublikasikan laporan keuangan auditan selama periode 2014-2017, dan 3) Perusahaan yang tidak mempunya ekuitas negatif. Berdasarkan kriteria tersebut, terdapat 106 perusahaan manufaktur yang dapat dijadikan sampel dalam penelitian ini.

\section{Definisi Operasional dan Pengukuran Variabel}

Variabel yang digunakan dalam penelitian ini adalah :

\section{Variabel Dependen}

\section{Nilai Perusahaan}

Nilai perusahaan dalam penelitian ini diukur dengan menggunakan Price Book Value (PBV), dimana menurut Jogiyanto (2000) dalam Analisa (2011), rasio PBV menunjukkan seberapa jauh suatu perusahaan mampu menciptakan nilai perusahaan yang relatif terhadap jumlah modal yang diinvestasikan. PBV yang tinggi mencerminkan harga saham yang tinggi dibandingkan nilai buku per lembar saham, yang berarti semakin berhasil perusahaan menciptakan nilai bagi pemegang saham. Rumus untuk menghitung PBV adalah sebagai berikut:

$$
\text { PBV }=\frac{\text { Harga Saham Per Lembar Saham }}{\text { Nilai Buku Per Lembar Saham }}
$$

Untuk menghitung Nilai Buku Per Lembar saham dapat digunakan rumus sebagai berikut:

$$
\text { NB/lembar saham }=\underline{\text { Total Ekuitas }}
$$

Jumlah saham yang beredar

\section{Variabel Independen}

\section{Kebijakan Hutang}

Kebijakan hutang dalam penelitian ini diukur dengan menggunakan Debt to Equity Ratio (DER), dimana menurut Mardiyati dkk (2012), tujuan dari rasio ini adalah untuk mengukur kemampuan perusahaan dalam membayar hutang-hutang yang dimilikinya dengan modal atau ekuitas yang ada. Rasio ini menunjukkan perbandingan antara pembiayaan dan pendanaan melalui hutang dengan pendanaan 
melalui ekuitas. Rumus untuk menghitung DER adalah sebagai berikut:

$$
\text { DER }=\frac{\text { Total Hutang }}{\text { Total Ekuitas }}
$$

\section{Ukuran Perusahaan}

Dalam penelitian ini, ukuran perusahaan dilihat dari total assets yang dimiliki oleh perusahaan, yang dapat dipergunakan untuk kegiatan operasi perusahaan. Alat ukur ini digunakan untuk mengurangi perbedaan signifikan antara ukuran perusahaan yang terlalu besar dengan ukuran perusahaan yang terlalu kecil.

$$
\text { Size }=\operatorname{Ln}(\text { Total Assets })
$$

\section{Variabel Intervening}

\section{Agency Cost}

Agency cost dapat diproksikan dengan rasio discretionary expense terhadap total penjualan. Dalam formula ini rasio discretionary expense adalah seluruh beban yang dikeluarkan berdasarkan kebijaksanaan seorang manajer perusahaan yang meliputi beban operasi, beban non operasi, beban bunga serta beban gaji dan upah. Sementara total penjualan bersih adalah total penjualan yang sudah dikurangi dengan seluruh diskon , retur dan allowance (Lin,2006) dalam Fachrudin (2011).

\section{Agency cost $=\underline{\text { Discretionary expense }}$}

Net Sales

\section{Analisis Data}

Dalam penelitian ini, analisis data dilakukan dengan analisis jalur. Analisis ini digunakan karena terdapat kemungkinan hubungan antar variabel dalam model yang bersifat linier. Agency cost digunakan sebagai variabel intervening karena pengaruh kebijakan hutang dan ukuran perusahaan terhadap nilai perusahaan dapat berhubungan secara konseptual dengan rasio dicreationary expense terhadap penjualan sebagai proksi agency cost. Secara teori pengaruh kebijakan hutang dan ukuran perusahaan terhadap nilai perusahaan dapat terlihat secara langsung. Namun dapat pula dilihat melalui agency cost. Analisis jalur pada penelitian ini dilakukan dengan menggunakan software SPSS (Statistical Package for Social Science) Versi 20.0 for window. Analisis statistic yang digunakan meliputi analisis statistik deskriptif, uji asumsi klasik yang terdiri dari uji normalitas, uji multikolinearitas, uji heteroskedastisitas, dan uji autokorelasi. Pengujian hipotesis menggunakan uji t dan uji F. Tingkat signifikansi yang digunakan adalah 0.05 . 
Persamaan struktural untuk pengujian hipotesis adalah:

$$
\begin{aligned}
& \mathrm{Y}_{1}=\rho \mathrm{Y}_{1} \mathrm{X}_{1} \mathrm{X}_{1}+\rho \mathrm{Y}_{1} \mathrm{X}_{2} \mathrm{X}_{2}+\epsilon_{1} \\
& \mathrm{Y}_{2}=\rho \mathrm{Y}_{2} \mathrm{X}_{1} \mathrm{X}_{1}+\rho \mathrm{Y}_{2} \mathrm{X}_{2} \mathrm{X}_{2}+\rho \mathrm{Y}_{2} \mathrm{Y}_{1} \mathrm{Y}_{1}+\epsilon_{2}
\end{aligned}
$$

Keterangan:

Y1 : variabel dependen agency cost

Y2 : variabel dependen kinerja perusahaan

X1 : variabel independen kebijakan hutang

X2 : variabel independen ukuran perusahaan

$\rho Y 1 X 1$ : koefisien jalur X1 ke Y1

$\rho Y 1 X 2$ : koefisien jalur X2 ke Y1

$\rho Y 2 X 1$ : koefisien jalur X1 ke Y2

$\rho Y 2 X 2$ : koefisien jalur X2 ke Y2

$\rho Y 2 Y 1$ : koefisien jalur Y1 ke Y2

$€ 1 \quad$ : koefisien jalur variabel error 1

$€ 2 \quad$ : koefisien jalur variabel error 2

\section{HASIL PENELITIAN DAN PEMBAHASAN}

Berikut ini disajikan hasil uji statistik. Adapun data dan hasil pengolahannya secara lengkap ada pada penulis. Data awal yang dimasukkan berupa variabel kebijakan hutang, ukuran perusahaan, dan agency cost (sub struktur I) dan variabel kebijakan hutang, ukuran perusahaan, agency cost dan nilai perusahaan (sub struktur II) tidak menunjukkan bahwa residual tidak memenuhi uji normalitas. Untuk itu data ditransformasi dalam bentuk logaritma natural. Karena data sesuai populasi sasaran adalah data yang tidak memiliki ekuitas negatif, maka seluruh data yang ditransformasi dapat terbaca oleh alat analisis.

\section{Hasil Pengujian Asumsi Klasik Sub Struktur I}

1. Uji Normalitas

Uji normalitas dilihat dari grafik normal plot menunjukkan hasil bahwa titik-titik menyebar di sekitar garis diagonal serta penyebarannya mengikuti arah garis diagonal, hal ini menunjukan bahwa model regresi layak dipakai karena memenuhi asumsi normalitas. Hasil ini juga diperkuat oleh uji normalitas 
menggunakan One-Sampel Kolmogorov-Smirnov Test dengan nilai signifikansinya adalah sebesar 0.670 yang menunjukkan bahwa nilai signifikansi $>0.05$. Dengan demikian nilai residualnya terdistribusi secara normal.

2. Uji Mulitikolinearitas

Nilai tolerance masing-masing variabel adalah 0.964, yang lebih besar dari 0.1. Nilai VIF sebesar 1.037, yang lebih kecil dari 10. Berdasarkan hasil tersebut, maka dapat disimpulkan bahwa semua variabel independen dalam model regresi tidak terdapat masalah multikolinearitas dan layak digunakan dalam penelitian ini.

3. Uji Heteroskedastisitas

Dengan melihat grafik scatterplots, terlihat bahwa titik-titik menyebar secara acak serta tersebar baik di atas maupun di bawah angka 0 pada sumbu Y. Hal ini dapat disimpulkan bahwa tidak terjadi heteroskedasitas pada model regresi, sehingga model regresi layak dipakai untuk memprediksi agency cost berdasarkan masukkan variabel kebijakan hutang dan ukuran perusahaan.

4. Uji Autokorelasi

Dengan menggunakan uji LM Test, diperoleh nilai $\mathrm{X}^{2}$ hitung $(166,662)<\mathrm{X}^{2}$ tabel $(447,632)$, maka model persamaan regresi tidak mengandung masalah autokorelasi.

\section{Hasil Pengujian Asumsi Klasik Sub Struktur II}

1. Uji Normalitas

Uji normalitas dilihat dari grafik normal plot menunjukkan hasil titik-titik menyebar di sekitar garis diagonal serta penyebarannya mengikuti arah garis diagonal, hal ini menunjukan bahwa model regresi layak dipakai karena memenuhi asumsi normalitas. Hasil ini juga diperkuat oleh uji normalitas menggunakan One-Sampel Kolmogorov-Smirnov Test dengan nilai signifikansinya adalah sebesar 0.059 yang menunjukkan bahwa nilai signifikansi $>0.05$. Dengan demikian nilai residualnya terdistribusi secara normal.

2. Uji Mulitikolinearitas

Nilai tolerance masing-masing variabel adalah $0.956,0.962$, dan 0.987 , yang lebih besar dari 0.1. Nilai VIF sebesar 1.046, 1.039, dan 1.013 yang lebih kecil dari 10. Berdasarkan hasil tersebut, maka dapat disimpulkan bahwa semua variabel independen dalam model regresi tidak terdapat masalah multikolinearitas dan layak digunakan dalam penelitian ini.

3. Uji Heteroskedastisitas 
Dengan melihat grafik scatterplots, terlihat bahwa titik-titik menyebar secara acak serta tersebar baik di atas maupun di bawah angka 0 pada sumbu Y. Hal ini dapat disimpulkan bahwa tidak terjadi heteroskedasitas pada model regresi, sehingga model regresi layak dipakai untuk memprediksi nilai perusahaan berdasarkan masukkan variabel kebijakan hutang, ukuran perusahaan dan agency cost.

4. Uji Autokorelasi

Dengan menggunakan uji LM Test, diperoleh nilai $\mathrm{X}^{2}$ hitung $(173,430)<\mathrm{X}^{2}$ tabel $(447,632)$, maka model persamaan regresi tidak mengandung masalah autokorelasi.

\section{Hasil Pengujian Hipotesis}

Berikut adalah hasil pengujian hipotesis dalam penelitian ini:

Tabel 1. Hasil Pengujian Hipotesis

\begin{tabular}{|c|c|c|c|c|c|c|c|c|}
\hline Model & Variabel Independen & Variabel Dependen & $\begin{array}{c}\text { Koefisien } \\
\text { Jalur }\end{array}$ & t-value & Sig & F-value & Sig & R Square \\
\hline \multirow{2}{*}{$\begin{array}{l}\text { Sub } \\
\text { Struktur I }\end{array}$} & Kebijakan Hutang & \multirow[t]{2}{*}{ Agency Cost } & $-0,093$ & $-1,890$ & 0,059 & \multirow[t]{2}{*}{2,789} & \multirow[t]{2}{*}{0,063} & \multirow[t]{2}{*}{0,013} \\
\hline & Ukuran Perusahaan & & $-0,051$ & $-1,034$ & 0,302 & & & \\
\hline \multirow{3}{*}{$\begin{array}{l}\text { Sub } \\
\text { Struktur II }\end{array}$} & Kebijakan Hutang & \multirow[t]{3}{*}{ Nilai Perusahaan } & $-0,058$ & $-1,218$ & 0,224 & \multirow[t]{3}{*}{14,024} & \multirow[t]{3}{*}{0,000} & \multirow[t]{3}{*}{0,091} \\
\hline & Ukuran Perusahaan & & 0,209 & 4,396 & 0,000 & & & \\
\hline & Agency Cost & & 0,229 & 4,897 & 0,000 & & & \\
\hline
\end{tabular}

\section{Hasil uji hipotesis sub struktur I}

Pengujian secara parsial ( $\mathrm{t}$ test), yakni melihat pengaruh setiap variabel independen terhadap dependen, didapat hasil sebagai berikut:

a. X1 didapatkan Sig $=0,059(\mathrm{p}>0,05)$. Artinya variabel X1 secara parsial tidak berpengaruh terhadap variabel Y1. Hal ini menunjukkan bahwa hipotesis pertama yang menyatakan bahwa kebijakan hutang berpengaruh negatif terhadap agency cost tidak dapat diterima atau ditolak.

b. X2 didapatkan Sig $=0,302(\mathrm{p}>0,05)$. Artinya variabel X2 secara parsial tidak berpengaruh terhadap variabel Y1. Hal ini menunjukkan bahwa hipotesis kedua yang menyatakan bahwa ukuran perusahaan berpengaruh positif terhadap agency cost tidak dapat diterima atau ditolak.

Hasil uji signifikansi simultan ( $F$ test) menunjukkan nilai $F$ sebesar 2,789 dengan probabilitas signifikansi 0,063 lebih besar dari 0,05, maka dapat ditarik kesimpulan bahwa kebijakan hutang dan ukuran perusahaan secara bersama-sama (simultan) tidak berpengaruh terhadap agency cost. 
Pada tabel juga dapat dilihat bahwa untuk sub struktur I yang digunakan untuk menganalisis pengaruh kebijakan hutang dan ukuran perusahaan terhadap agency cost didapatkan $R$ Square, yaitu $\mathrm{R}^{2}=0,013=1,3 \%$. Hal ini menunjukkan kontribusi variabel independen terhadap dependen sebesar $1,3 \%$. Artinya kebijakan hutang dan ukuran perusahaan hanya mampu menjelaskan hubungannya dengan agency cost sebesar 1,3\% saja. Sedangkan sisanya yaitu 98,7\% besarnya agency cost disebabkan oleh variabel lain yang tidak diteliti dalam penelitian ini. Sementara itu, untuk nilai $€ 1$ dapat dicari dengan rumus $€ 1=\sqrt{ }\left(1-\mathrm{R}^{2}\right)$, sehingga di dapatkan hasil $€ 1=\sqrt{ }(1-$ $0,013)=0,993$.

Pada hasil uji persamaan regresi sub struktur I diperoleh nilai standardized beta kebijakan hutang dan ukuran perusahaan sebesar -0,093 dan -0,051. Nilai standardized beta merupakan koefisien jalur masing-masing variabel yang menunjukkan kontribusi dari masing-masing variabel independen terhadap dependen.

Didapatkan persamaan jalurnya sebagai berikut:

$\mathrm{Y} 1=-0,093 \mathrm{X} 1-0,051 \mathrm{X} 2+0,993 € 1$

\section{Hasil uji hipotesis sub struktur II}

Pengujian secara parsial ( $\mathrm{t}$ test), yakni melihat pengaruh setiap variabel independen terhadap dependen, didapat hasil sebagai berikut:

1. X1 didapatkan Sig $=0,224(\mathrm{p}>0,05)$. Artinya variabel $\mathrm{X} 1$ secara parsial tidak berpengaruh terhadap variabel Y2. Hal ini menunjukkan bahwa hipotesis ketiga yang menyatakan kebijakan hutang berpengaruh positif terhadap nilai perusahaan tidak dapat diterima atau ditolak.

2. $\mathrm{X} 2$ didapatkan Sig $=0,000(\mathrm{p}<0,05)$ dengan koefisien jalur 0,209 . Artinya variabel X2 secara parsial berpengaruh positif terhadap variabel Y2. Hal ini menunjukkan bahwa hipotesis keempat yang menyatakan ukuran perusahaa berpengaruh positif terhadap nilai perusahaan dapat diterima.

3. Y1 didapatkan Sig $=0,000(p<0,05)$ dengan koefisien jalur 0,229 . Artinya variabel Y1 secara parsial berpengaruh positif terhadap variabel Y2. Hal ini menunjukkan bahwa hipotesis kelima yang menyatakan agency cost berpengaruh negatif terhadap nilai perusahaan tidak dapat diterima.

Hasil uji signifikansi simultan (F test) menunjukkan nilai F sebesar 14,024 dengan probabilitas signifikansi 0,000 lebih kecil dari 0,05, maka dapat ditarik kesimpulan bahwa kebijakan hutang, ukuran perusahaan dan agency cost secara bersama-sama (simultan) berpengaruh terhadap nilai perusahaan.

Pada tabel juga dapat dilihat bahwa untuk sub struktur II yang digunakan untuk mengetahui pengaruh kebijakan hutang, ukuran perusahaan dan agency cost terhadap nilai perusahaan yang diproksikan dengan PBV, seperti yang terlihat pada 
tabel menghasilkan niai $R$ Square, yaitu $\mathrm{R}^{2}=0,091=9,1 \%$. Hal ini menunjukkan kontribusi variabel independen terhadap dependen sebesar 9,1\%. Artinya kebijakan hutang, ukuran perusahaan dan agency cost hanya mampu menjelaskan hubungannya dengan nilai perusahaan sebesar 9,1\% saja. Sedangkan sisanya yaitu 90,9\% besarnya nilai perusahaan disebabkan oleh variabel lain yang tidak diteliti dalam penelitian ini. Sementara itu, untuk nilai $€ 2$ dapat dicari dengan rumus $€ 2=\sqrt{ }\left(1-R^{2}\right)$, sehingga di dapatkan hasil $€ 1=\sqrt{ }(1-0,091)=0,953$.

Pada hasil uji persamaan regresi sub struktur II diperoleh nilai standardized beta kebijakan hutang, ukuran perusahaan dan agency cost sebesar -0,058, 0,209 dan 0,229 . Nilai standardized beta merupakan koefisien jalur masing-masing variabel yang menunjukkan kontribusi dari masing-masing variabel independen terhadap dependen.

Didapatkan persamaan jalurnya sebagai berikut:

$\mathrm{Y} 2=-0,058 \mathrm{X} 1+0,209 \mathrm{X} 2+0,229 \mathrm{Y} 1+0,953 € 2$

\section{Pengaruh X1 terhadap Y2 melalui Y1}

Untuk analisis pengaruh tidak langsung antara variabel kebijakan hutang (X1) terhadap nilai perusahaan (Y2) melalui variabel agency cost (Y1) dapat diketahui dengan cara perkalian antara nilai beta X1 terhadap Y1 dengan nilai beta Y1 terhadap Y2 yaitu : $-0,093 \times 0,229=-0,021$. Maka pengaruh total yang diberikan X1 terhadap Y2 adalah pengaruh langsung ditambah dengan pengaruh tidak langsung yaitu : $0,058-0,021=-0,079$. Berdasarkan hasil perhitungan di atas diketahui bahwa nilai pengaruh langsung sebesar -0,058 dan pengaruh tidak langsung sebesar -0,021 yang berarti bahwa nilai pengaruh tidak langsung lebih besar dibandingkan dengan nilai pengaruh langsung.

\section{Pengaruh X2 terhadap Y2 melalui Y1}

Untuk analisis pengaruh tidak langsung antara variabel ukuran perusahaan (X2) terhadap nilai perusahaan (Y2) melalui variabel agency cost (Y1) dapat diketahui dengan cara perkalian antara nilai beta X2 terhadap Y1 dengan nilai beta Y1 terhadap Y2 yaitu : $-0,051 \times 0,229=-0,012$. Maka pengaruh total yang diberikan X2 terhadap Y2 adalah pengaruh langsung ditambah dengan pengaruh tidak langsung yaitu : 0,209 - 0,012 = 0,197. Berdasarkan hasil perhitungan di atas diketahui bahwa nilai pengaruh langsung sebesar 0,209 dan pengaruh tidak langsung sebesar -0,012 yang berarti bahwa nilai pengaruh langsung lebih besar dibandingkan dengan nilai pengaruh tidak langsung. 


\section{ANALISIS HASIL PENGUJIAN}

\section{Pengaruh Kebijakan Hutang terhadap Agency cost}

Kebijakan hutang diukur dengan debt equity ratio (DER), dimana tujuan dari rasio ini adalah untuk mengukur kemampuan perusahaan dalam membayar hutang-hutang yang dimilikinya dengan modal atau ekuitas yang ada. Hasil penelitian menunjukkan tingkat signifikan sebesar 0,059>0,05 dengan koefisien jalur sebesar -0,093, sehingga dapat diperoleh bahwa pengaruh kebijakan hutang terhadap agency cost memiliki arah negatif, tetapi hanya memiliki kontribusi yang sedikit karena tingkat signifikan lebih dari 0,05. Hal ini berarti bahwa hipotesis pertama yang menyatakan kebijakan hutang berpengaruh negatif terhadap agency cost tidak dapat diterima.

Berdasarkan teori yang menghubungkan agency cost dengan hutang dalam struktur modal, yang menyatakan bahwa penggunaan hutang dalam struktur modal dapat mencegah pengeluaran perusahaan yang tidak penting dan memberi dorongan pada manajer untuk mengoperasikan perusahaan dengan lebih efesien sehingga menyebabkan agency cost berkurang. Teori ini tidak mendukung hipotesis pertama. Hasil penelitian ini sejalan dengan penelitian yang dilakukan oleh Immanuela (2014. Hal ini dapat disebabkan karena perusahaan dengan jumlah hutangnya yang banyak maupun sedikit, tidak membuat perusahaan lebih berhati-hati dalam melakukan pengeluaran-pengeluaran dalam hal ini discretionary expense.

\section{Pengaruh Ukuran Perusahaan terhadap Agency cost}

Ukuran perusahaan merupakan salah satu ukuran dalam menentukan besar kecilnya biaya agensi (agency cost) yang dikeluarkan oleh perusahaan. Salah satu tolak ukur yang menunjukkan besar kecilnya perusahaan adalah total aset dari perusahaan tersebut. Semakin besar total aset yang dimiliki suatu perusahaan semakin besar pula ukuran perusahaan suatu perusahaan. Biasanya semakin besar ukuran perusahaan maka semakin komplek masalah agensi yang dihadapi. Hal ini karena perusahaan dengan jumlah besar sulit memonitoring, sehingga menyebabkan agency cost semakin meningkat.

Berdasarkan uji t dengan melihat nilai signifikansi dari variabel ukuran perusahaan dengan menggunakan proksi Log Natural Total Assets memiliki nilai sig sebesar 0,302 > 0,05 dengan koefisien jalur sebesar -0,051. Artinya hasil dari penelitian yang telah dilakukan menunjukkan ukuran perusahaan tidak memiliki pengaruh positif terhadap agency cost yang diproksikan dengan discretionary expense. Hal ini berarti bahwa semakin besar ukuran perusahaan, agency cost yang ditimbulkan tidak akan selalu lebih tinggi, begitu pula sebaliknya semakin kecil ukuran perusahaan, agency cost yang ditimbulkan tidak akan selalu lebih rendah.. Penelitian ini mendukung hasil penelitian yang dilakukan oleh Immanuela (2014) dan Pratiwi, Tandika, dan Nurdin (2015). Dimana ukuran perusahaan tidak berpengaruh positif terhadap agency cost dapat disebabkan karena ukuran perusahaan pada 
sampel penelitian banyak yang memiliki ukuran perusahaan yang besar dengan total aset yang besar sehingga perusahaan tidak terlalu memikirkan discretionary expense yang akan dikeluarkan, baik discretionary expense yang tinggi ataupun discretionary expense yang rendah.

\section{Pengaruh Kebijakan Hutang terhadap Nilai Perusahaan}

Bagi perusahaan yang menerbitkan saham di pasar modal, harga saham yang diperjualbelikan di bursa merupakan indikator nilai perusahaan. Penambahan utang pada titik tertentu akan meningkatkan tingkat pengembalian yang diharapkan yang akan menaikkan harga saham tersebut. Modigliani dan Miller (1963) dalam Budiati (2013) berpendapat bahwa semakin tinggi proporsi hutang pada suatu perusahaan maka nilai perusahaan akan semakin meningkat. Hal ini disebabkan karena adanya keuntungan dari pengurangan pajak karena adanya pembayaran bunga yang dibayarkan oleh perusahaan sebagai akibat dari penggunaan hutang.

Brigham dan Houston (2011) menyatakan bahwa peningkatan hutang diartikan oleh pihak luar sebagai kemampuan perusahaan untuk membayar kewajiban di masa yang akan datang dimana hal tersebut akan akan memperoleh respon positif oleh pasar. Penggunaan hutang dapat mengurangi penghasilan kena pajak karena perusahaan diwajibkan untuk membayar bunga pinjaman. Pengurangan pajak dapat menambah laba perusahaan yang bisa dimanfaatkan untuk reinvestasi ataupun untuk pembagian dividen kepada para pemegang saham. Reinvestasi dan pembagian dividen akan meningkatkan penilaian investor sehingga dapat meningkatkan minat mereka untuk membeli saham.

Berdasarkan uji t dengan melihat nilai signifikansi dari variabel kebijakan hutang dengan menggunakan proksi debt equity ratio (DER) memiliki nilai sig sebesar $0,224>0,05$ dengan koefisien jalur sebesar -0,058. Artinya hasil dari penelitian yang telah dilakukan menunjukkan kebijakan hutang tidak memiliki pengaruh positif terhadap nilai perusahaan yang diproksikan dengan Price Book Value (PBV). Hal ini berarti bahwa semakin besar jumlah hutang, tidak akan meningkatkan nilai perusahaan, begitu pula sebaliknya semakin kecil jumlah hutang, tidak akan menurunkan nilai perusahaan. Dengan kata lain, semakin tinggi atau rendah hutang yang dimiliki perusahaan tidak mampu mempengaruhi naik atau turunnya harga saham, sehingga investor atau pihak eksternal perusahaan tidak terlalu memperhatikan besar atau kecilnya hutang yang dimiliki oleh perusahaan tersebut. Penelitian ini mendukung penelitian yang dilakukan oleh Prastika (2012), Sofyaningsih dan Hardiningsih (2012), Hemastuti (2014), Hidayah dan Widyawati (2016).

\section{Pengaruh Ukuran Perusahaan terhadap Nilai Perusahaan}


Ukuran perusahaan mempunyai pengaruh yang berbeda terhadap nilai perusahaan.. Perusahaan-perusahaan besar dianggap memiliki kontrol yang lebih baik terhadap kondisi pasar, sehingga mereka mampu menghadapi persaingan ekonomi, yang membuat mereka menjadi kurang rentan terhadap fluktuasi ekonomi. Perusahaanperusahaan besar juga mempunyai lebih banyak sumber daya untuk meningkatkan nilai perusahaan karena memiliki akses yang lebih baik terhadap sumber-sumber informasi eksternal dibandingkan dengan perusahaan kecil. Ukuran perusahaan yang besar menunjukkan perusahaan mengalami perkembangan sehingga investor akan merespon positif dan nilai perusahaan akan meningkat. Semakin besar perusahaan atau skala perusahaan maka akan semakin mudah pula perusahaan memperoleh sumber pendanaan baik bersifat internal maupun eksternal, sehingga juga dapat meningkatkan nilai perusahaan. Dalam hal ukuran perusahaan yang dilihat dari total aset yang dimiliki oleh perusahaan, yang dapat dipergunakan untuk kegiatan operasi perusahaan

Berdasarkan uji t dengan melihat nilai signifikansi dari variabel ukuran perusahaan dengan menggunakan proksi Log Natural Total Assets memiliki nilai sig sebesar $0.000<0.05$ dengan koefisien jalur 0,209. Artinya hasil penelitian yang telah dilakukan menunjukkan ukuran perusahaan memiliki pengaruh positif terhadap nilai perusahaan yang diproksikan dengan price book value (PBV), berarti semakin besar ukuran suatu perusahaan akan menyebabkan meningkatnya nilai perusahaan. Begitu pula sebaliknya, semakin kecil ukuran suatu perusahaan akan menurunkan nilai perusahaan. Dalam penelitian ini menunjukkan bahwa investor mempertimbangkan ukuran perusahaan dalam membeli saham. Hasil penelitian ini mendukung penelitian yang dilakukan oleh Analisa (2011), Nurhayati (2013), Ernawati dan Widyawati (2015) dimana ukuran perusahaan dapat berpengaruh positif terhadap nilai perusahaan yang dapat disebabkan karena ukuran perusahaan pada sampel penelitian banyak yang memiliki ukuran perusahaan yang besar, sehingga ada kecenderungan lebih banyak investor yang menaruh perhatian pada perusahaan tersebut. Dan juga perusahaan besar dapat dengan mudah mengakses ke pasar modal. Kemudahan untuk mengakses ke pasar modal berarti perusahaan memiliki fleksibilitas dan kemampuan untuk mendapatkan dana, karena kemudahan aksebilitas ke pasar modal dan kemampuannya untuk memunculkan dana lebih besar. Adanya kemudahan tersebut ditangkap oleh investor sebagai sinyal positif, sehingga dapat meningkatkan nilai perusahaan.

\section{Pengaruh Agency cost terhadap Nilai Perusahaan}

Agency cost merupakan biaya yang dikeluarkan oleh pemegang saham (pemilik) untuk meyakinkan agar manajer bekerja sungguh-sungguh untuk kepentingan pemegang saham. Agency cost diproksikan dengan rasio discretionary expense terhadap total penjualan. Dalam formula ini rasio discretionary expense adalah seluruh beban yang dikeluarkan berdasarkan kebijaksanaan seorang manajer 
perusahaan yang meliputi beban operasi, beban non operasi, beban bunga serta beban gaji dan upah. Jika discretionary expense yang dikeluarkan semakin besar terhadap jumlah penjualan, maka akan mengurangi laba perusahaan. Laba perusahaan yang kecil membuat investor tidak tertarik untuk berinvestasi di perusahaan tersebut, sehingga rendahnya permintaan beli atas saham yang menyebabkan harga saham terus menurun yang mengakibatkan nilai perusahaan juga ikut menurun. Begitu juga sebaliknya, jika discretionary expense yang dikeluarkan semakin kecil terhadap jumlah penjualan, maka akan meningkatkan laba perusahaan yang mengakibatkan nilai perusahaan meningkat.

Berdasarkan uji t dengan melihat nilai signifikansi dari variabel ukuran perusahaan dengan menggunakan proksi Log Natural Total Assets memiliki nilai sig sebesar $0.000<0.05$ dengan koefisien jalur 0,229 . Artinya hasil penelitian yang telah dilakukan menunjukkan agency cost memiliki pengaruh positif terhadap nilai perusahaan yang diproksikan dengan Price Book Value (PBV). Hasil penelitian ini berbeda dengan hipotesis yang menyatakan bahwa agency cost berpengaruh negatif terhadap nilai perusahaan, karena agency cost yang kecil akan meningkatkan laba perusahaan yang akan berdampak pada meningkatnya nilai perusahaan. Tetapi berdasarkan hasil penelitian, semakin besarnya agency cost maka akan meningkatkan nilai perusahaan. Penelitian ini mendukung penelitian yang dilakukan oleh Naftaly, Safitri, dan Wijaya (2015). Dimana agency cost yang berpengaruh positif terhadap nilai perusahaan dapat disebabkan karena dengan semakin tingginya agency cost berarti semakin besar biaya yang dikeluarkan oleh perusahaan dalam rangka memastikan manajemen agar bekerja bersungguh-sungguh sesuai dengan kepentingan pemegang saham, sehingga hal tersebut mampu mengurangi kekhawatiran pemegang saham jika manajemen bekerja bukan untuk kepentingan pemegang saham tersebut, sehingga memberikan pandangan yang positif bagi pemegang saham dalam menilai perusahaan.

\section{Pengaruh Kebijakan Hutang terhadap Nilai Perusahaan melalui Agency cost}

Pengujian hipotesis kebijakan hutang berpengaruh positif terhadap nilai perusahaan melalui agency cost diperoleh nilai koefisien jalur sebesar -0,021. Hasil pengujian hipotesis kebijakan hutang berpengaruh negatif terhadap agency cost ditolak, hasil pengujian hipotesis kebijakan hutang berpengaruh positif terhadap nilai perusahaan ditolak, dan hasil pengujian hipotesis agency cost berpengaruh negatif terhadap nilai perusahaan juga ditolak. Hal ini menunjukkan bahwa agency cost yang diproksikan dengan discretionary expense tidak mampu memediasi hubungan kebijakan hutang dengan nilai perusahaan. Hal ini juga berarti bahwa penggunaan hutang dalam struktur modal tidak dapat mempengaruhi besar atau kecilnya agency cost yang akan berdampak pada laba perusahaan sehingga tidak menyebabkan meningkat atau menurunnya nilai perusahaan. 


\section{Pengaruh Ukuran Perusahaan terhadap Nilai Perusahaan melalui Agency cost}

Pengujian hipotesis ukuran perusahaan berpengaruh negatif terhadap nilai perusahaan melalui agency cost diperoleh nilai koefisien jalur sebesar -0,012. Hasil pengujian hipotesis ukuran perusahaan berpengaruh positif terhadap agency cost ditolak, hasil pengujian hipotesis ukuran perusahaan berpengaruh positif terhadap nilai perusahaan diterima, dan hasil pengujian hipotesis agency cost berpengaruh negatif terhadap nilai perusahaan ditolak. Sementara koefisien jalur pengaruh tidak langsung ukuran perusahaan terhadap nilai perusahaan melalui agency cost lebih kecil dibandingkan dengan pengaruh langsung ukuran perusahaan terhadap nilai perusahaan dengan koefisien jalur 0,209. Hal ini menunjukkan bahwa agency cost yang diproksikan dengan discretionary expense tidak mampu memediasi hubungan ukuran perusahaan dengan nilai perusahaan. Hal ini dapat disebabkan karena kebanyakan dari sampel dalam penelitian ini adalah perusahaan besar dengan total aset yang besar, sehingga tidak terlalu memperhatikan besar atau kecilnya agency cost yang dikeluarkan yang akan berpengaruh terhadap laba perusahaan dan mampu meningkatkan atau menurunkan nilai perusahaan.

\section{KESIMPULAN DAN SARAN}

Berdasarkan hasil pengujian disimpulkan bahwa secara parsial kebijakan hutang tidak berpengaruh negatif terhadap agency cost, ukuran perusahaan tidak berpengaruh positif terhadap agency cost, kebijakan hutang tidak berpengaruh positif terhadap nilai perusahaan, ukuran perusahaan berpengaruh positif terhadap nilai perusahaan, agency cost tidak berpengaruh negatif terhadap nilai perusahaan, serta kebijakan hutang tidak berpengaruh positif terhadap nilai perusahaan melalui agency cost sebagai variabel intervening, dan ukuran perusahaan tidak berpengaruh negatif terhadap nilai perusahaan melalui agency cost sebagai variabel intervening.

Peneliti selanjutnya dapat meningkatkan penelitian ini dengan menambahkan faktor-faktor lain yang mempengaruhi nilai perusahaan. Peneliti selanjutnya juga dapat melakukan penelitian berdasarkan sektor perusahaan manufaktur yang terdaftar di Bursa Efek Indonesia, seperti sektor industri dasar dan kimia, sektor aneka industri, dan sektor industri barang konsumsi dengan menggunakan rasio lain untuk mengukur nilai perusahaan, karena nilai perusahaan yang telah go public mungkin tidak hanya terlihat dari harga sahamnya.

\section{REFERENSI}

(1) Analisa, Y. (2011). Pengaruh ukuran perusahaan, leverage, profitabilitas dan kebijakan dividen terhadap nilai perusahaan : Studi pada perusahaan manufaktur yang terdaftar di Bursa Efek Indonesia tahun 2006-2008. Skripsi Sarjana Fakultas Ekonomi Universitas Diponegoro. 
(2) Atmaja, S.L. (1999). Manajemen Keuangan. Edisi revisi dilengkapi soal-soal. Yogyakarta : Penerbit Andi.

(3) Barros, Lucas Ayres B. de C. and Alexandre Di Miceli da Silveira. (2007). Overconfidence, Managerial Optimisme and the Determinants of Capital Structure. Journal of Finance. Available on line at www.ssrn.com

(4) Brigham, E.F, dan Houston, J.F. (2006). Fundamentals of financial management dasar-dasar manajemen keuangan. Buku 1 Edisi Kesepuluh. Jakarta : Salemba Empat.

(5) Brigham, E.F, dan Houston, J.F. (2006). Fundamentals of financial management dasar-dasar manajemen keuangan. Buku 2 Edisi Kesepuluh. Jakarta : Salemba Empat.

(6) Budiati, S.S. (2013). Analisis pengaruh insider ownership, kebijakan utang dan dividen terhadap nilai perusahaan pada perusahaan manufaktur yang terdaftar di bursa efek indonesia (BEI). Jurnal Manajemen. Universitas Negeri Padang.

(7) Dewi, A.S.M., dan Wirajaya, A. (2013). Pengaruh struktur modal, profitabilitas dan ukuran perusahaan. E-Jurnal Akuntansi Universitas Udayana 4.2, 358-372.

(8) Ernawati, D., dan Widyawati, D. (2015). pengaruh profitabilitas, leverage, dan ukuran perusahaan terhadap nilai perusahaan. Jurnal Ilmu \& Riset Akuntansi, Vol. 4 No. 4, 1-17. STIESIA Surabaya.

(9) Fachrudin, K.A. (2011). Analisis pengaruh struktur modal, ukuran perusahaan, dan agency cost terhadap kinerja perusahaan. Jurnal Akuntansi dan Keuangan, Vol.13, No. 1, 37-46.

(10) Ghozali, I. (2013). Aplikasi Analisis Multivariate dengan Program SPSS. Semarang : UNDIP.

(11) Harmono. (2011). Manajemen keuangan berbasis balanced scorecard pendekatan teori, kasus, dan riset bisnis. Jakarta: Bumi Aksara.

(12) Hemastuti, C.P., dan Hermanto, S.B. (2014). Pengaruh profitabilitas, kebijakan dividen, kebijakan hutang, keputusan investasi dan kepemilikan insider terhadap nilai perusahaan. Jurnal Ilmu dan Riset Akuntansi, Vol. 3 No. 4.

(13) Hidayah, N., dan Widyawati, D. (2016). Pengaruh profitabilitas, leverage, dan kebijakan dividen terhadap nilai perusahaan food and beverages. Jurnal Ilmu dan Riset Akuntansi, Vol. 5, Nomor 9. 
(14) Husnan, S., dan Pudjiastuti, E. (1998). Dasar-dasar manajemen keuangan. Edisi Kedua. Yogyakarta : UPP AMP YKPN

(15) Immanuela, I. (2014). Pengaruh kempemilikan manajerial, struktur modal, ukuran perusahaan, dan agency cost sebagai variabel intervening terhadap kinerja perusahaan pada perusahaan manufaktur yang terdaftar di BEI. Widya Warta, No. 01, ISSN 0854-1981, 59-70. Universitas Katolik Widya Mandala Madiun.

(16) Jensen, M.C., and Meckling, W.H. (1976). Theory of the Firm: Managerial Behavior, Agency Cost and Ownership Structure. Journal of Financial Economics.

(17) Kaen, F.R., \& Baumann, H. (2003). Firm Size, Employees and Profitability in U.S Manufacturing Industries. Journal of Economic Literature.

(18) Mardiyati, U., Ahmad, G.N., dan Putri, R. (2012). Pengaruh kebijakan dividen, kebijakan hutang dan profitabilitas terhadap nilai perusahaan manufaktur yang terdaftar di BEI periode 2005-2010. Jurnal Riset Manajemen Sains Indonesia, Vol.3, No. 1

(19) Naftaly, M., Safitri, L., dan Wijaya, T. (2015). Analisis pengaruh agency cost dan corporate social responsibility terhadap nilai perusahaan manufaktur periode 2010-2014.

(20) Nuraina, E. (2012). Pengaruh kepemilikan institusional dan ukuran perusahaan terhadap kebijakan hutang dan nilai perusahaan (studi pada perusahaan manufaktur yang terdaftar di BEI). Jurnal Akuntansi, 51-70.

(21) Nurhayati, M. (2013). Profitabilitas, likuiditas dan ukuran perusahaan pengaruhnya terhadap kebijakan dividen dan nilai perusahaan sektor non jasa. Jurnal Keuangan dan Bisnis, Vol. 5, No. 2

(22) Pracihara, S.M. (2016). Pengaruh kebijakan hutang, kepemilikan manajerial, kebijakan dividen, dan ukuran perusahaan terhadap nilai perusahaan (studi pada sektor pertambangan yang terdaftar di BEI periode 2011-2014). Jurnal Ilmu Manajemen. Universitas Negeri Surabaya. 
(23) Prastika, Ni Gst. Ayu Pt. S. (2012). Pengaruh Ios, Leverage, Dan Dividend Yield Terhadap Profitabilitas Dan Nilai Perusahaan Sektor Manufaktur Di BEI. Jurnal Magister Manajemen Universitas Udayana.

(24) Pratiwi, N.I., Tandika, D., dan Nurdin. (2017). Pengaruh struktur modal dan ukuran perusahaan terhadap agency cost pada industri barang konsumsi yang terdaftar di Bursa Efek Indonesia (BEI) pada periode 2012-2015. Prosiding Manajemen. Volume. 3, No. 1, 200-205.

(25) Putri, N.R. (2017). Permintaan meningkat, industri manufaktur tumbuh signifikan. Ditelusuri 27 November 2017. https://kumparan.com/noviantirahmi-putri/permintaan-meningkat-industri-manufaktur-tumbuhsignifikan\#z6FFbY74m0H7sbEF.99

(26) Putu, N.N.G.M., Djumahir, Moeljadi, dan Djazuli, A. (2014). Factors Affecting Firms Value of Indonesia Public Manufacturing. International Journal of Business and Management Invention. Vol. 3 (2): pp 35-44.

(27) Sofyaningsih, S., dan Hardiningsih, P. (2011). Struktur kepemilikan, kebijakan dividen, kebijakan hutang dan nilai perusahaan. Dinamika Keuangan dan Perbankan, Vol. 3, No. 1, Hal 68-87.

(28) Suharli, M. (2006). Studi empiris terhadap faktor-faktor yang mempengaruhi nilai perusahaan pada perusahaan go public di Indonesia. Jurnal Maksi. Vol. 6, No. 1, 23-41. Universitas Katolik Indonesia Atma Jaya. 